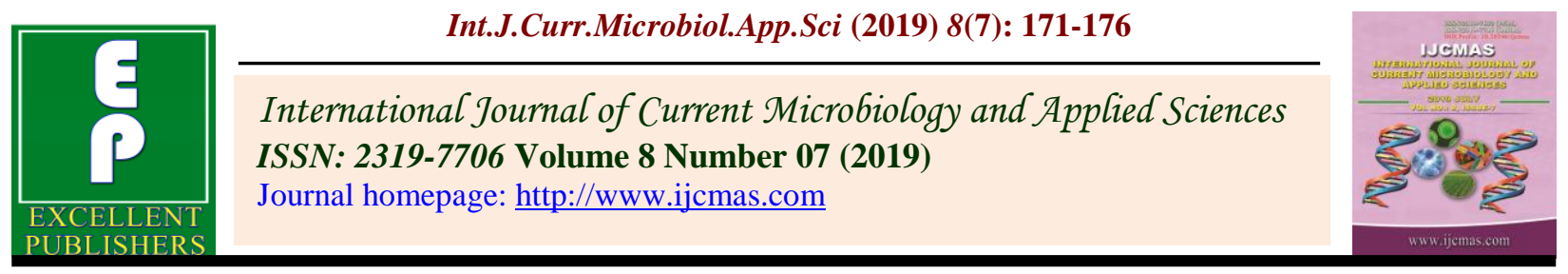

Original Research Article

https://doi.org/10.20546/ijcmas.2019.807.021

\title{
Utility Perception and Its Relationship with Profile Characteristics of the Users of Kisan Mobile Advisory Service (KMAS)
}

\author{
M.B. Shinde*, D.D. Suradkar and P.T. Shinde \\ Department of Extension Education, College of Agriculture, Latur, Vasantrao Naik \\ Marathwada Krishi Vidyapeeth, Parbhani-431402 (M.S.), India \\ *Corresponding author
}

\begin{tabular}{|l|}
\hline Key w ord s \\
Utility perception, \\
KMAS, KVK \\
\hline Article Info \\
\hline Accepted: \\
04 June 2019 \\
Available Online: \\
10 July 2019 \\
\hline
\end{tabular}

A B S T R A C T

The study was conducted in Latur district of Marathwada region. Population for the study comprised of respondents who were subscriber of Kisan Mobile Advisory Service in Latur district. From latur district Latur, Ausa and Renapur tahsils were selected purposively because more number of farmers in these tahsils were using KMAS. Proportionate sampling method used in selection of respondents, thus total sample size was one hundred and twenty respondents which who are subscribers of KMAS. One shot case study method of ex-postfacto research design was adopted for this study. Data was coded, tabulated, analysed and interpreted using suitable statistical parameters. The results showed that most of the users $(70.84 \%)$ had medium utility perception and independent variables like farming experience, education, cropping pattern, extension contacts, mass media utilization, decision making ability, economic motivation, innovative proneness, cosmopoliteness had positive and significant relationship with utility perception. Whereas land holding and annual income were do not showed significant relationship with utility perception.

\section{Introduction}

Kisan Mobile Advisory Service scheme in main line extension system of Krishi Vigyan Kendras (KVK) is new ICT initiatives to meet the needs and expectations of the farmers. KMAS is started by ICAR with the aim of passing the agricultural information to maximum number of farmers in local language through SMS free of cost. Kisan Mobile Advisory Service (KMAS) delivers real-time agricultural information and customized knowledge to improve farmers decision making ability so that they may enable to increase their production and productivity, better aligning the farm output to market demands; securing better quality and improved price recovery in a globally competitive agrarian economy. Utility perception refers to the process of perceiving the usefulness of external objects, events and information by means of senses. The 
favourable utility perception of farmers towards KMAS as an effective and efficient information support tool would lead to stronger conviction towards changing agrirural environment.

\section{Materials and Methods}

Population for the study comprised of respondents who were subscriber of Kisan Mobile Advisory Service in Latur district. From latur district Latur, Ausa and Renapur tahsils were selected purposively because more number of farmers in these tahsils were using KMAS. Proportionate sampling method used in selection of respondents, thus total sample size was one hundred and twenty respondents which who are subscribers of KMAS. One shot case study method of expost-facto research design was adopted for this study. The scale of 14 items to measure utility perception of users towards KMAS was developed with help of teacher to quantify utility perception of KVK KMAS as perceived by users. Utility perception of users of KVK KMAS was measured by computing the utility perception score. Final score was calculated by combining all scores and made as category low (upto 38), medium (39-42) and high comfortable (43\& above).

\section{Results and Discussion}

\section{Profile characteristics of the KMAS users}

The first objective of the study was to describe profile characteristics of KMAS users. The distributional analysis pertaining to farming experience of the respondents indicated that, majority $(62.50 \%)$ of the respondents were from medium farming experience, majority $(40.00 \%)$ of the respondents belonged to secondary education category, 40.00 per cent respondents had semi-medium land holding (2.01 to 4 ha), majority $(79.16 \%)$ of the farmers were growing soybean followed by sorghum (57.50 \%), Pigeon pea (41.66\%) during kharif and during rabi season majority $(71.66 \%)$ of the farmers were growing chick pea followed by wheat $(65.00 \%)$ (Table 1$)$.

Also in summer groundnut were grown while sugarcane was grown as annual and very few farmers grown perennials $(56.67 \%)$ respondents had high annual income above (Rs.94,754 and above), majority (75.00\%) of respondents belonged to medium extension contact, $(74.16 \%)$ of respondents had medium mass media utilization, More than half $(62.50 \%)$ of the cases the respondents belong to medium decision making ability, $(54.16 \%)$ respondents had high economic motivation, larger proportion $(65.50 \%)$ of the respondents belonged to medium innovative proneness and 64.16 per cent respondents were belonged to the medium cosmopoliteness.

\section{Utility Perception Index (UPI)}

The utility perception of the KMAS as perceived by the users including 14 dimensions under each dimensions sub items were developed and the data were collected according from each respondent. They were scored analysed and utility perception index of the dimensions were worked out, this are presented in Table 2.

The dimension of utility perception namely $(93.33 \%)$ had more than 93 UPI and had been ranked I, followed by Readability $(92.63 \%)$, Economic viability (92.08\%), Accuracy of information (91.94\%) and Understand ability $(91.25 \%)$, were ranked II, III, IV and V respectively. Whereas ranked Innovativeness (90.83\%), Location specific (90.62\%), Clarity (90.55), Sustainability (90.41\%), Timeliness (88.75\%), Credibility (87.50\%) Applicability $(86.80 \%)$, Coverage of subject matter $(86.67 \%)$ and Satisfaction $(80.27 \%)$ ranked VI, VII, VIII, IX, X, XI, XII, XIII and XIV respectively. 
Table.1 Profile characteristics of KMAS users $(\mathrm{N}=120)$

\begin{tabular}{|c|c|c|c|}
\hline Profile characters & Category & Frequency & Percentage \\
\hline \multirow{3}{*}{ Farming experience } & Low (Up to 14 years) & 22 & 18.34 \\
\hline & Medium(15 to 27 years) & 75 & 62.50 \\
\hline & High (28 years and above) & 23 & 19.16 \\
\hline \multirow[t]{10}{*}{ Education } & Illiterate & 00 & 00.00 \\
\hline & Only read and write & 05 & 04.16 \\
\hline & Primary education (Std $1^{\text {st }}$ to $\left.4^{\text {th }}\right)$ & 07 & 05.83 \\
\hline & Secondary education (Std $5^{\text {th }}$ to $10^{\text {th }}$ ) & 48 & 40.00 \\
\hline & Higher secondary education $\left(11^{\text {th }}\right.$ to $\left.12^{\text {th }}\right)$ & 36 & 30.00 \\
\hline & Diploma & 03 & 02.50 \\
\hline & Graduated & 17 & 14.16 \\
\hline & Post Graduate & 02 & 01.66 \\
\hline & Ph.D. & 00 & 00.00 \\
\hline & Other & 00 & 00.00 \\
\hline \multirow[t]{5}{*}{ Land holding } & Marginal (up to 1 ha) & 20 & 16.67 \\
\hline & Small (1.01 to 2.00$)$ & 35 & 29.16 \\
\hline & Semi-medium (2.01 to 4.00$)$ & 48 & 40.00 \\
\hline & Medium (4.01 to 10.00$)$ & 15 & 12.50 \\
\hline & Big (10.01 and above) & 02 & 01.67 \\
\hline \multicolumn{4}{|l|}{ Cropping pattern } \\
\hline \multirow[t]{6}{*}{ (Kharif) } & Soybean & 95 & 79.16 \\
\hline & Sorghum & 69 & 57.50 \\
\hline & Pigeon pea & 50 & 41.66 \\
\hline & Black gram & 25 & 20.83 \\
\hline & Green gram & 49 & 40.83 \\
\hline & Sunflower & 29 & 24.16 \\
\hline \multirow[t]{4}{*}{ (Rabi) } & Chick pea & 86 & 71.66 \\
\hline & Wheat & 78 & 65.00 \\
\hline & Sorghum & 28 & 23.33 \\
\hline & Safflower & 25 & 20.83 \\
\hline \multirow[t]{3}{*}{ (Summer) } & Groundnut & 49 & 40.83 \\
\hline & Maize (Fodder) & 39 & 32.50 \\
\hline & Vegetable & 13 & 10.83 \\
\hline (Annual) & Sugarcane & 41 & 34.16 \\
\hline \multirow[t]{3}{*}{ (Perennial) } & Mango & 3 & 04.16 \\
\hline & Sapota & 2 & 01.66 \\
\hline & Banana & 1 & 00.83 \\
\hline \multirow[t]{3}{*}{ Annual income } & Low (Up to 62,818$)$ & 12 & 10.00 \\
\hline & Medium $(62,819$ to 94,753$)$ & 40 & 33.33 \\
\hline & High $(94,754$ and above $)$ & 68 & 56.67 \\
\hline
\end{tabular}




\begin{tabular}{|l|l|l|l|}
\hline Extension contact & Low (Up to 14) & 16 & 13.33 \\
\hline & Medium (15 to 22) & 90 & 75.00 \\
\hline $\begin{array}{l}\text { Mass } \\
\text { utilization }\end{array}$ & High (23 and above) & 14 & 11.67 \\
\hline & Low (Up to 3) & 12 & 10.00 \\
\hline $\begin{array}{l}\text { Decision making } \\
\text { ability }\end{array}$ & Medium (4 to 5) & Low (Up to 14) & \\
\hline & Medium (15 to 16) & 89 & 74.16 \\
\hline $\begin{array}{l}\text { Economic } \\
\text { motivation }\end{array}$ & High (17 and above) & 19 & 15.83 \\
\hline & Low (Up to 13) & 25 & 20.84 \\
\hline $\begin{array}{l}\text { Innovative } \\
\text { proneness }\end{array}$ & Medium (14 to 15) & 75 & 62.50 \\
\hline & High (16 and above) & 20 & 16.66 \\
\hline Cow (Up to 15) & 21 & 17.50 \\
\hline & Medium (16 to 17) & 65 & 54.16 \\
\hline & High (18 and above) & 34 & 28.34 \\
\hline & Low (Up to 1) & 12 & 10.00 \\
\hline & Medium (2 to 3) & 78 & 65.00 \\
\hline & High (4 and above) & 30 & 25.00 \\
\hline
\end{tabular}

Table.2 Utility perception of users about various dimensions of Kisan Mobile Advisory service

\begin{tabular}{|c|c|c|c|}
\hline $\begin{array}{l}\text { Sl. } \\
\text { No. }\end{array}$ & Category & $\begin{array}{l}\text { Utility Perception } \\
\text { Index }\end{array}$ & Rank \\
\hline 1 & Readability & 92.63 & II \\
\hline 2 & Credibility & 87.50 & XI \\
\hline 3 & Timeliness & 88.75 & $\mathrm{X}$ \\
\hline 4 & Understandability & 91.25 & $\mathrm{~V}$ \\
\hline 5 & Applicability & 86.80 & XII \\
\hline 6 & Accuracy of Information & 91.94 & IV \\
\hline 7 & Coverage of subject matter & 86.67 & XIII \\
\hline 8 & Clarity & 90.55 & VIII \\
\hline 9 & Location specific & 90.62 & VII \\
\hline 10 & Sustainability & 90.41 & IX \\
\hline 11 & Economic viability & 92.08 & III \\
\hline 12 & Decision making ability & 93.33 & I \\
\hline 13 & Innovativeness & 90.83 & VI \\
\hline 14 & Satisfaction & 80.27 & XIV \\
\hline
\end{tabular}


Table.3 Distribution of the respondents according to their overall utility perception ( $\mathrm{N}=120)$

\begin{tabular}{|l|l|l|l|}
\hline Sl. No. & Utility Perception & Frequency & Percentage \\
\hline 1. & Low (Up to 38) & 11 & 09.16 \\
\hline 2. & Medium (39 to 42) & 85 & 70.84 \\
\hline 3. & High (43 and above) & 24 & 20.00 \\
\hline
\end{tabular}

Table.4 Relationship between independent and dependent variables

\begin{tabular}{|l|l|l|}
\hline Sl. No. & Variables & 'r' value \\
\hline $\mathbf{1 .}$ & Farming experience & $0.196^{*}$ \\
\hline $\mathbf{2 .}$ & Education & $0.275^{* *}$ \\
\hline $\mathbf{3 .}$ & Land holding & $0.116^{\mathrm{NS}}$ \\
\hline $\mathbf{4 .}$ & Cropping pattern & $0.204^{*}$ \\
\hline $\mathbf{5 .}$ & Annual income & $0.054^{\mathrm{NS}}$ \\
\hline $\mathbf{6 .}$ & Extension contacts & $0.362^{* *}$ \\
\hline $\mathbf{7 .}$ & Mass media utilization & $0.343^{* *}$ \\
\hline $\mathbf{8 .}$ & Decision making ability & $0.302^{* *}$ \\
\hline $\mathbf{9 .}$ & Economic motivation & $0.253^{*}$ \\
\hline $\mathbf{1 0 .}$ & Innovative proneness & $0.227^{*}$ \\
\hline $\mathbf{1 1}$. & Cosmopoliteness & $0.213^{*}$ \\
\hline
\end{tabular}

* \& ** correlation is significant at the 0.05 and 0.01 level respectively.

NS - Non significant

The overall utility of KMAS SMS as perceived by users seems to be medium as per their distribution on utility perception categories. However, the utility perception index of components like readability, economic viability, accuracy of information and understand ability was high. This may be due to the reason that the information provided through Kisan Mobile Advisory Service (KMAS) was factual, illustrate and readable. Further innovativeness, location specific, clarity, sustainability, timeliness and credibility of KMAS had better utility perception. Also applicability, coverage of subject matter and Satisfaction about KMAS was good.

It has been observed from the Table 3 majority of respondent $(70.84 \%)$ had medium utility perception, followed by high utility perception $(20.00 \%)$ and low utility perception $(09.16 \%)$. Thus the overall utility perception of Kisan Mobile Advisory Service was medium.

The findings of research are in line with Patidar (2010), Dhakar (2012).

\section{Relationship between the profile characteristics and utility perception}

The results revealed that out of eleven independent variables, nine variables had exhibited positive significant relationship with existing utility perception of the respondents. farming experience, education, cropping pattern, extension contacts, mass media utilization, decision making ability, economic motivation, innovative proneness, cosmopoliteness had positive and significant relationship with Utility perception. Whereas land holding and annual income were do not 
showed significant relationship with Utility perception (Table 4).

It was concluded that, majority of the respondents from medium farming experience, secondary education category, semi-medium land holding, majority are grown soybean in kharif, high annual income, medium extension contact, medium mass media utilization, medium decision making, high economic motivation. Regarding the other variables like innovative proneness and cosmopoliteness found in medium category. Also clearly observed that, majority of the respondents had medium utility perception. Study clearly indicates that majority of the registered farmer perceived the KMAS messages had medium utility perception the information sent by KMAS. Therefore, it is suggested that other farmers who have not registered for KMAS, can be motivated to use KMAS service by creating awareness through mass medias by Krishi Vignyan Kendras (KVKs).

\section{References}

Dhakar, K. S., (2012). A study on utility perception of farmers in relation to modern mass media under information communication technology in Rewa district. M.Sc. (Agri.) Thesis, JNKVV, Jabalpur.

Gurjar, P. K. S., Singh, L., Gurjar, L. S., Jatar,
C. B. S., Haldar and Yadagiri, J.(2015).

Farmer's Response on Kisan Mobile Advisory: A Critical Evaluation. Plant Archives 15 (2):885-887.

Kanavi, S. P., (2014). An analysis of Kisan Mobile Advisory Services (KMAS) of Krishi Vigyan Kendra. M.Sc. (Agri.) Thesis, Univ. Agric. Sci., Dharwad

Patel, M. R. Patel, M. V. and Patel, R.A., (2015).Assessment of Kisan Mobile Advisory (KMA) Service for Dissemination of Agriculture Information in Mehsana District; Gujarat. International Journal on Recent and Innovation Trends in Computing and Communication 3(7): 4599-4602.

Patidar, J., (2010). Study on utility perception and expectation of paddy growers, regarding information communication technology in Hanumana block of Rewa district (M.P.). M.Sc. (Agri.) Thesis, JNKVV, Jabalpur.

Patra, J., Singh, D. V. and Patil, J. K., (2016). Kisan Mobile Advisory Service- An Effective ICT Tool for Technology Dissemination. International Journal of Humanities and Social Science Invention. 5(6): 68-72.

Shinde M.R., (2016). Utility perception of VNMKV calender by the readers. M.Sc. (Agri.) Thesis, MAU, Parbhani.

\section{How to cite this article:}

Shinde, M.B., D.D. Suradkar and Shinde, P.T. 2019. Utility Perception and Its Relationship with Profile Characteristics of the Users of Kisan Mobile Advisory Service (KMAS). Int.J.Curr.Microbiol.App.Sci. 8(07): 171-176. doi: https://doi.org/10.20546/ijcmas.2019.807.021 